\title{
Frank Ruda, Hegel's Rabble: An Investigation into Hegel's Philosophy of Right
}

\author{
London: Continuum, 2011, 218pp., ISBN 978-1441156938
}

\author{
Reviewed by Søren Rosendal \\ Aarhus University
}

The best and most precise philosophical commentaries are rarely the ones that take a view-from-nowhere approach and try to give a general and "neutral" account of the text, but are more often the ones that have a highly specific angle, even an agenda, engaging with the text beyond its limited historical context. Frank Ruda's book Hegel's Rabble is exemplary of this latter type, letting Hegel's philosophy refract through the notion of the "rabble" and following the repercussions this has for his Philosophy of Right and beyond. Ruda's approach is so fruitful because it insists on reanimating rather than simply and solely reinterpreting the text. Pöbel, or "The rabble" can be provisionally defined as Hegel does in \$244 of the Philosophy of Right: destitute poverty coupled with a negative attitude that unbinds this "class" from the sphere of right so that it disintegrates from society and falls into a state of inactivity.

Whilst reading Ruda's long woven strands of beautiful argumentation and association through the twelve closely linked chapters of the book, one is led in interpretative detail through backdoors and avenues of the Hegelian system, drawing unexpected connections that suddenly lead to radically non-Hegelian territory. This approach is justified because the rabble marks the point within the system that threatens to explode, or at least irritate, the system in its present form, so in order to account for the rabble within Hegel one needs to move beyond Hegel. This is the governing methodological thought throughout.

In Frank Ruda's reading, the rabble is not simply a minor issue in a specific part of a specific section of Hegel's political philosophy, but represents "a fundamental irritation of philosophy by politics" (4). This means that the phenomenon of the "rabble" forces philosophy to rethink its own fundamental logic. It presents a negative "experience" in the Hegelian sense of the word, the collapse of a fundamental criterion of truth or distinction. Classical political philosophical concepts such as equality, justice, and freedom need to be readdressed in the light, or 
shadow, of the rabble. But also concepts such as necessity and contingency and especially the central Hegelian opposition between determinacy and indeterminacy are at stake.

Ruda takes his point of departure from Hegel's admission that civil society produces poverty by necessity due to its own internal dynamics. His project could be summed up as describing the disintegrative process whereby this by-product of civil society falls into utter socio-political indeterminacy and the consequences and potential that this process unleashes. The strength of the book lies in a strongly argued insistence that the rabble presents a reorientation fundamental to post-Hegelian thinking. Ruda starts off by focusing on the "structural irresolvability" (31) of poverty within civil society that is diagnosed but left unsolved by Hegel. The emergence of the rabble is a kind of pure negation, defined as "a nothing that surfaces within civil society" (32), but by the sheer fact of being "nothing" (not belonging to an estate, not represented politically, not participating in social institutions, etc.) it is also the possibility of transformation. The point is not to "solve" the problem of the rabble, to find a way to neutralize it by reorganizing society, but rather that the rabble is in itself a point of political (and philosophical) transformation. To bring out the consequence of the deadlock presented by both the phenomenon and concept of the rabble, Ruda, both implicitly and explicitly, fuses the loose ends of Hegel with Alain Badiou's theoretical edifice (the influence of Jacques Rancière and Slavoj Žižek also echoes throughout; the latter also wrote the preface for the book).

For the rabble to appear, more is needed than simply poverty. It also needs to have a set of attitudes whereby it gradually unbinds itself from society: it refuses to work for its own subsistence, it is part of no estate, no cooperation, it sees no rationality in the organized whole of the state, feels indignation, resentment, and so on. But surprisingly the rabble need not even be poor, because not only is there a process of unbinding originating from the very bottom, there is also an unbinding at the upper strata of civil society. The latter is the "luxury rabble" epitomized in the gambler who circumvents the mediations opened by civil society and exploits its inherent pathologies for fast wealth (or fast loss) extracted from the contingent "game" of civil society. Civil society is, so to speak, disintegrating at both ends. Both are the asocial products of the social order, neither integrated within the sphere of right nor duty. One of the most exciting parts of the book is exactly this reading of Hegel's analyses of the juxtaposition of the poor rabble as a necessary possibility (everyone is latently poor, since poverty is necessarily produced, and thus everyone is latently rabble) and the rich rabble as contingent possibility (gambling with contingencies of the market to produce contingent wealth). The possibilities that structure civil society are also the possibilities of its inherent pathologies; these two sides cannot be separated, but determine each other. 
Throughout the book Ruda gradually focuses more and more on the process that unbinds the rabble from all connections to ethical communality, society, and the state. But in this unbinding it also claims what Ruda characterizes as a right without right, that is, the insistence on a right but without participation in the institutions of right. The privation or unbinding that gives rise to the rabble opens a fundamental and universal level of politics: in a sense the absolute rabble is the zero-level of politics, because all members of society are latently rabble. The rabble is not just a particular (excluded) class within society, but the absolute indeterminacy upon which all socio-political determinacy is (always already) conferred. But its "presence" is therefore only retroactively experienced as the consequence of the dissolution inherent to civil society. It also cannot be directly accounted for in that it operates "below" official political representation. Here we are in the territory of Badiou's "void” (2005: 31-69): that which is withdrawn from all presentation (the count-as-one) and therefore is only present as absent, yet with a foundational function, since all presentations are presentations of this void. This is a kind of insubstantial universality, because anyone is latently rabble (the only thing-in modern society-that all participate in is the potential for becoming rabble). Also in characterizing the rabble as losing its habit of being active and falling into an inert will resembles Agamben's notion of "impotentiality" (1999: 177-84), it has fully withdrawn itself from actualization while still being there, being nothing.

The process of in-determination and unbinding, "the absolute negation of all determinations" (163) that is the rabble is characterized in several ways by Ruda, who adeptly shifts between metaphors and concepts of the Hegelian corpus while interconnecting it in original ways with the contemporary thinkers already mentioned in a way that sheds new light on both sides. The central theme running through the book is the indetermination of the rabble. And it is exactly this indetermination that raises some fascinating questions that I would like to address.

I think it is safe to say that Hegel was very critical of pure indeterminacy, and Ruda is explicit in his declaration that this goes beyond and even against Hegel, but in what sense is the rabble this absolute or pure indeterminacy? For Hegel, pure indeterminacy can only "exist" as a destructive process of negations: not-this, not-this, not-this etc., as in the Terror following the French Revolution-the guillotine is a machine for the eradication of determinacy (of anyone daring to specify what abstract universal freedom actually is). Is the pure indeterminacy of the rabble in Ruda's book akin to this negative process? At one point he writes: "The appearing of the rabble is its disappearing" (132), which seems to go against the non-dialectical character of the absolute rabble. And is the rabble not determined, for example, by it making a demand of a right without right? Maybe the "nothing" that the rabble is should only be understood as a nothing from the point of view of the socio-political order, a "nothing" 
that presents the underlying truth of the order that it itself cannot represent (to itself)?

Another question pertains to the status of the right without right, especially with regard to equality. If this is a "right," formulated outside the sphere of right, that demands equality and justice based on the fact that everyone is universally latently rabble, then is this not the equality of (the possibility of) universal destitution? The rabble is "the Hegelian name for the emergence of an indeterminacy which decomposes the state" (164), thus the rabble is the name for universal decomposition, the dissolution at the ground of the apparent integration of society. But is the most fundamental level always the most dissolved level (this question could also be addressed to Badiou)? And what positive political force can be gained from the declaration that we are all equal as latently destitute? Can the pure and "impossible" demand for universal equality and justice as the point of political transformation be based solely on indeterminacy and dissolution? This then leads to the shift in the last pages of the book where "nothing" in a sense becomes "everything." The determination of man is to have no prior determination, which is how Ruda reads Marx's notion of Gattungswesen; man can become anything and everything in "universal production." But what is not addressed is how this re-determination of the absolutely indeterminate man is itself possible.

Despite its apparently narrow focus, Hegel's Rabble covers all of Hegel's Philosophy of Right and crucial aspects of the Philosophy of Spirit ${ }^{1}$ in an extremely rich yet very precise way that effortlessly surpasses the boundary between commentary and original philosophical contribution. Frank Ruda's important and groundbreaking piece of careful, daring argumentation comes highly recommended not just for anyone interested in Hegel but more universally, for anyone interested in contemporary politics and philosophy.

\section{Bibliography}

Agamben, Giorgio (1999). Potentialies. Stanford: Stanford University Press. Badiou, Alan (2005). Being and Event. London: Continuum.

Hegel, G. W. F. (2008). Outlines of the Philosophy of Right. Ed. Stephen Houlgate, trans.

T. M. Knox. Oxford: Oxford University Press.

Hegel, G. W. F. (2010). Philosophy of Mind. Ed. Michael Inwood, trans. W. Wallace and A. V. Miller. Oxford: Oxford University Press.

1 In the English translation, "Spirit” (Geist) is somewhat misleadingly translated as "Mind." 